\title{
Shareholder Litigation Under Indeterminate Corporate Law
}

\author{
Ehud Kamar†
}

\section{INTRODUCTION}

One of the least explained phenomena in American corporate law is the puzzling circularity of director and officer liability insurance and indemnification. Under the auspices of state corporate law, virtually all public corporations use internal and external insurance to protect their boards and management from liability for breach of fiduciary duties. ${ }^{1}$ The concept of liability insurance and indemnification in relation to shareholder fiduciary claims seems on its face futile. Arguably, there is no utility for shareholders in suing corporate fiduciaries for damages when fi-

† John M. Olin Fellow, Columbia University Center for Law and Economic Studies. I benefited greatly from the comments of William Allen, Jennifer Arlen, Ian Ayres, Kyle Bagwell, Dan Bailey, Franklin Balotti, Lisa Bernstein, Bernard Black, Bruce Chapman, John Coffee, Kevin Davis, Erik Durbin, Frank Easterbrook, Richard Epstein, Michal Gal, Ronald Gilson, Victor Goldberg, Jeffrey Gordon, Gillian Hadfield, Edward Iacobucci, Joseph Johnston, Marcel Kahan, Reinier Kraakman, Jeffrey MacIntosh, Joseph Monteleone, Mitchell Polinsky, Chris Sanchirico, Marshall Small, Eric Talley, Michael Trebilcock, Aaron Van Oort, and participants in The University of Chicago Law Review Symposium Formalism Revisited and the University of Toronto Law and Economics Workshop. Special thanks go to Paul Mahoney for his most illuminating Comment on this Article. The Columbia University Center for Law and Economic Studies provided generous financial support. This Article was written in partial fulfillment of the requirements for the degree of Doctor of the Science of Law in the Faculty of Law, Columbia University.

1 Of the 1,386 United States firms that participated in a 1998 survey, 92 percent reported purchasing director and officer liability insurance. Insurance was even more prevalent among publicly traded firms. Of the survey participants with 500 or more shareholders, 98 percent reported having coverage. Moreover, every survey participant who conducted an initial public offering within the last five years reported having coverage. See 1998 Directors and Officers Liability Survey: U.S. and Canadian Results 8-17 (Tillinghast-Towers Perrin 1999) ("Towers Perrin Liability Survey"). Similarly, practically all public corporations have bylaw provisions that mandate the extension of indemnification rights whenever indemnification is permissible. See Advanced Mining Systems, Inc v Fricke, 623 A2d 82, 83 (Del Chanc 1992). Most state laws limit indemnification in shareholder derivative suits to expenses incurred during the suit. In contrast, insurance may reimburse defendants both for expenses and for amounts paid in settlements or judgments. See, for example, 8 Del Code Ann $\$ 145$ (a)-(b) (1998); Cal Corp Code $\$ 317(c)$ (West 1999); NY Bus Corp Law §§ 722(c), 726 (McKinney 1999); Revised Model Bus Corp Act $\$ 8.51$ (c) (1994). As a practical matter, insurers reimburse firms for indemnification payments made to individual defendants (corporate reimbursement coverage) and reimburse individual defendants for payments not indemnified (personal coverage). See John F. Olson and Josiah O. Hatch III, Director and Officer Liability: Indemnification and Insurance $\S 10.05$ at 10-13, -14 (West 1998); Towers Perrin Liability Survey at 30. 
duciaries pay most of these damages using funds provided by shareholders. ${ }^{2}$ The resulting transaction and litigation costs simply seem superfluous. ${ }^{3}$

This Article argues that insurance and indemnification can be a socially desirable mechanism that induces plaintiffs to sue yet keeps sanctions low. Although litigation is costly, and should ordinarily be kept at a minimum, shareholder litigation can be cost effective in view of the indeterminacy that characterizes corporate law. American corporate law relies heavily on open-ended legal standards that grant courts wide discretion in resolving corporate disputes. Rather than provide corporate actors with bright line rules that delineate proper behavior, the law provides only inconclusive criteria that courts may deem relevant when applying the standards ex post. Corporate actors who try to plan their behavior in accordance with the law must therefore assesswith some uncertainty-where the threshold of liability lies. ${ }^{4}$ The

2 Circularity is complete in the case of derivative suits, where directors and officers are the defendants and all shareholders sue on behalf of the firm. In the case of class actions, such as suits brought by shareholders who tendered their shares in a management buyout or another freezeout merger, both the firm and its directors and officers are the defendants. Here, insurance and indemnification is circular only with respect to liability allocated to directors and officers. However, this portion is substantial and normally exceeds half the liability.

- As Paul Mahoney rightly points out, liability insurance and indemnification would not be puzzling if its cost was deducted from director and officer pay. See Paul G. Mahoney, The First Thing We Do, Let's Pay All the Lawyers, 66 U Chi L Rev 922, 923 (1999). See also Steven Shavell, On liability and insurance, 13 Bell J Econ 120 (1982). In practice, however, director and officer pay does not seem to reflect this cost. See John E. Core, On the Corporate Demand for Directors' and Officers' Insurance, $64 \mathrm{~J}$ Risk \& Ins 63 (1997) (finding no support in a sample of Canadian firms for the hypothesis that liability insurance substitutes for cash compensation paid to directors); John E. Core, The Directors' and Officers' Insurance Premium: An Outside Assessment of the Cost of Weak Corporate Governance 22-24 (Feb 15, 1999) (on file with U Chi I Rev) (finding that both insurance premiums and chief executive pay are higher when corporate governance mechanisms are weak in a sample of Canadian firms). Similarly, while litigation typically drives insurance costs up, it has no measurable effect on managerial compensation. See Roberta Romano, The Shareholder Suit: Litigation without Foundation?, 7 J L Econ \& Org 55, 71 (1991) (finding no changes in managerial compensation following litigation in a sample of American firms). For the argument that contracts between corporate fiduciaries and shareholders are generally not the product of efficient bargaining, see Victor Brudney, Corporate Governance, Agency Costs, and the Rhetoric of Contract, 85 Colum L Rev 1403 (1985). For the argument that director and officer compensation in particular cannot fully reflect legal exposure, see Reinier Kraakman, Hyun Park, and Steven Shavell, When Are Shareholder Suits in Shareholder Interests?, 82 Georgetown L J 1733, 1745-48 (1994).

- For an analysis of the indeterminacy in corporate law, as epitomized by Delaware law, see Ehud Kamar, A Regulatory Competition Theory of Indeterminacy in Corporate Law, 98 Colum L Rev 1908, 1913-18 (1998). The duty of loyalty is no exception to this general pattern. Although corporate fiduciaries can reduce their liability risk by disclosing their conflict of interest to disinterested directors or shareholders and seeking their approval, following these steps does not preclude judicial inspection of both the decision and the way it was approved. For the flexible tests that are part of this inspection, see, for ex- 
absence of clear legal rules is costly. First, it leads to variance in assessments of the legal standard and thus to divergences of behavior from the social optimum. Some corporate fiduciaries may overestimate the legal constraints and forgo efficient transactions, while others may underestimate the very same constraints and carry out inefficient transactions. Second, legal indeterminacy creates liability risk, which risk-averse fiduciaries are in a poor position to bear. Exposing corporate fiduciaries to this risk makes their services more costly and less productive to shareholders.

The scenario just described bears on the optimal enforcement policy for corporate law. Normally, optimal enforcement is said to combine the highest sanctions defendants can bear with correspondingly low rates of enforcement. ${ }^{5}$ In civil law, this can be achieved through decoupled liability. ${ }^{6}$ While defendants pay the maximum possible, plaintiffs receive a lower amount, thus creating optimal deterrence with minimal litigation. However, legal indeterminacy in the corporate law context warrants the opposite type of decoupling, whereby defendants pay less than the maximum they can bear and plaintiffs -or, in shareholder suits, plaintiffs' attormeys-receive more than the defendant pays. Liability insurance and indemnification achieves precisely this effect. ${ }^{7}$

ample, Kahn v Tremont Corp, 694 A2d 422, 428 (Del 1997) (describing arm's length bargaining); Cinerama, Inc v Technicolor, Inc, 663 A2d 1156, 1167-68 (Del 1995) (evaluating an undisclosed material interest of board members); Cede \& Co v Technicolor, Inc, 634 A2d 345, 361-64 (Del 1993) (defining a material interest of board members in a transaction); Citron v Fairchild Camera and Instrument Corp, 569 A2d 53, 70 (Del 1989) (defining control of the corporation by a minority shareholder); Rosenblatt $v$ Getty Oil Co, 493 A2d 929, 944-45 (Del 1985) (setting the scope of disclosure to shareholders); Weinberger $v$ UOP, Inc, 457 A2d 701, 711 (Del 1983) (using an entire fairness standard); In re Tri-Star Pictures, Inc, 20 Del J Corp I 854, 862 (Del Chanc 1995) (addressing board domination).

S See Gary S. Becker, Crime and Punishment: An Economic Approach, $76 \mathrm{~J}$ Pol Econ 169 (1968). There are several exceptions to this. See, for example, A. Mitchell Polinsky and Steven Shavell, A Note on Optimal Fines When Wealth Varies Among Individuals, 81 Am Econ Rev 618 (1991) (income level); A. Mitchell Polinsky and Steven Shavell, The Optimal Use of Fines and Imprisonment, $24 \mathrm{~J}$ Pub Econ 89 (1984) (nonmonetary sanctions); A. Mitchell Polinsky and Steven Shavell, The Optimal Tradeoff between the Probability and Magnitude of Fines, 69 Am Econ Rev 880 (1979) (risk aversion).

- See A. Mitchell Polinsky and Yeon-Koo Che, Decoupling liability: optimal incentives for care and litigation, 22 RAND J Econ 562 (1991).

2 This explanation does not preclude other possible benefits of insurance and indemnification. According to one theory, liability insurers provide valuable monitoring services that justify the cost. See Clifford G. Holderness, Liability Insurers as Corporate Monitors, 10 Intl Rev L \& Econ 115, 116 (1990). See also Noel O'Sullivan, Insuring the Agents: The Role of Directors' and Officers' Insurance in Corporate Governance, $64 \mathrm{~J}$ Risk \& Ins 545 (1997) (finding substitutability between insurance and alternative monitoring devices in a sample of British firms). To the extent that such monitoring is effective, its value only adds to that of the decoupling mechanism described here. The decoupling rationale also complements the argument that firms buy liability insurance in order to lower expected 
The combination of less than maximum sanctions and high rates of enforcement is optimal for two reasons. First, litigation can reduce legal uncertainty. As decided cases accumulate, the interpretation and proper application of fiduciary standards become clearer, allowing directors and officers to estimate legal outcomes more accurately and thus to behave closer to the social optimum. ${ }^{8}$ Second, the combination of low sanctions and high enforcement also reduces the risk corporate fiduciaries bear. Insofar as fiduciaries are risk averse, their disutility from high and infrequent monetary sanctions exceeds their disutility from low and frequent sanctions, despite the fact that the expected sanction is the same. The difference between the two is a deadweight loss to society, which can be reduced by making sanctions low and frequent.

One clarification is in order. While I argue that liability insurance and indemnification can be an efficient response to a given level of indeterminacy in corporate law, I do not claim that it is efficient as practiced today. For one thing, litigation has costs, which must be weighed against any gains it generates. While the development of legal doctrine and reduction of liability risk are undeniably desirable, they may not justify the substantial costs of shareholder claims. Moreover, it is not clear that the current level of insurance and indemnification coverage is optimal. Insurance and indemnification may overprotect defendants from sanctions for breaches of fiduciary duty and encourage excessive filing and quick settlement of frivolous lawsuits. Finally, the extent to which corporate law relies on open-ended standards may or may not be efficient. Even if insurance and indemnifica-

bankruptcy losses. See David Mayers and Clifford W. Smith, Jr., On the Corporate Demand for Insurance, $55 \mathrm{~J}$ Bus 281, 284-85 (1982). Decoupling is effective independent of whether the burden that expected indemnity payments impose on firms is substantial. Others have justified insurance and indemnification on the basis that firms can benefit by protecting risk-averse fiduciaries from liability risk instead of increasing their direct compensation. See Mark E. Parry and Arthur E. Parry, The Purchase of Insurance by a RiskNeutral Firm for a Risk-Averse Agent, $58 \mathrm{~J}$ Risk \& Ins 30 (1991). Existing evidence, however, does not support the claim of substitutability between direct compensation and insurance. See note 3. By contrast, the decoupling rationale for insurance and indemnification is reinforced by, but does not depend upon, managerial risk aversion. Nor does the rationale depend on substitutability between direct compensation and insurance.

- For the role of precedents in clarifying the law, see Marcel Kahan and Michael Klausner, Standardization and Innovation in Corporate Contracting (or "The Economics of Boilerplate"), 83 Va L Rev 713, 722-23 (1997); Michael Klausner, Corporations, Corporate Law, and Networks of Contracts, 81 Va L Rev 757, 775-78 (1995); Louis Kaplow, Rules Versus Standards: An Economic Analysis, 42 Duke L J 557, 578-79, 611-16 (1992); Roberta Romano, Law as a Product: Some Pieces of the Incorporation Puzzle, $1 \mathrm{~J} \mathrm{~L}$ Econ \& Org 225, 277-78 (1985); William M. Landes and Richard A. Posner, Legal Precedent: A Theoretical and Empirical Analysis, $19 \mathrm{~J} \mathrm{~L} \mathrm{\&} \mathrm{Econ} \mathrm{249,} \mathrm{271-72} \mathrm{(1976).}$ 
tion serves as an efficient decoupling device in response to these standards, it is debatable whether its open-endedness is in all cases inescapable. ${ }^{9}$

The Article proceeds as follows. Part I analyzes the costs of indeterminacy in corporate law and makes the case for addressing indeterminacy by increasing enforcement and reducing sanctions. Part II explains how liability insurance and indemnification achieves the combination of high enforcement and low sanctions by serving as a decoupling device. Part III examines several considerations relevant for determining whether current insurance and indemnification practices achieve efficient decoupling, focusing on the cost of litigation, the need for decoupling to encourage litigation, the impact of insurance and indemnification on settlement rates, and the adequacy of deterrence where insurance and indemnification coverage is complete. The discussion then inquires whether state competition in corporate chartering can ensure that the current law is efficient in all of these respects, and concludes that it can do so only in a limited way. While competing states can benefit from addressing indeterminacy, they may lack the incentives to address it in the most efficient way.

\section{OPTIMAL ENFORCEMENT POLICY FOR CORPORATE LAW}

American corporate law is not an exact science. Rather, it is a set of loosely defined guidelines made concrete by courts after the fact. The message the guidelines carry, in general, is that corporate fiduciaries simply must do their utmost to promote shareholder interests. Exactly what this means in practice is not clear. Although court decisions list relevant criteria for judging managerial behavior, these criteria are not exhaustive. Indeed, courts often emphasize their incompleteness, leaving the legal community wondering what additional criteria may prove relevant in the future. ${ }^{10}$ The following discussion investigates the effects of this legal indeterminacy on social welfare and its implications for law enforcement. Drawing on the widely accepted idea that legal certainty is important for business planning, ${ }^{11}$ it argues that indeterminacy leads managerial behavior to diverge from

- The questionable efficiency of open-endedness in corporate law is analyzed in Kamar, 98 Colum L Rev 1908 (cited in note 4). This Article accordingly discusses the issue mostly by reference to that analysis.

${ }^{10}$ See the examples cited in note 4.

"See, for example, Kahan and Klausner, $83 \mathrm{Va} L$ Rev at 722-23 (cited in note 8); Klausner, $81 \mathrm{Va}$ L Rev at 777 (cited in note 8); Romano, $1 \mathrm{~J} \mathrm{~L} \mathrm{Econ} \mathrm{\&} \mathrm{Org} \mathrm{at} \mathrm{250-51} \mathrm{(cited}$ in note 8). 
the social optimum and exposes corporate fiduciaries to socially costly sanctions. ${ }^{12}$ The analysis then inquires what enforcement policy can minimize the costs of indeterminacy and concludes that a combination of moderate sanctions and frequent enforcement can best achieve this goal.

\section{A. The Costs of Indeterminacy in Corporate Law}

The primary cost of indeterminacy in corporate law is that it undermines the efficacy of the law in directing managerial behavior. No matter how strong the incentives to comply with the law, confusion about its precise meaning inevitably leads directors and officers to behave differently from the way they should. To see this, consider first a simple world in which a single criterion determines the propriety of managerial behavior, and the only uncertainty pertains to its degree. Suppose, for example, that price is the only relevant criterion for evaluating managerial behavior in management buyouts, ${ }^{13}$ and that the most one can glean from the precedents is that while a buyout price that far exceeds the current share price is likely to be upheld, a price only slightly higher than the current price may be deemed too low. In this scenario, different corporate fiduciaries may well have different estimates of the legally sufficient premium, and of their potential liability. ${ }^{14}$ As a result, their behavior will differ. Even if each fiduciary is prepared to bear the same expected liability,

\footnotetext{
${ }^{12}$ Needless to say, the discussion here refers only to behavior subject to judicial scrutiny. Even perfectly determinate law does not ensure that all decisions made by corporate fiduciaries are socially optimal. Many exroneous decisions receive full immunity under the business judgment rule. They are clearly not affected by the law. But in all areas of corporate activity outside the protection of the business judgment rule-that is, whenever law matters-indeterminacy is disruptive.

${ }^{13}$ In practice, judicial review of management buyouts is far more complex than a mere price adequacy test and includes other criteria, such as whether the board probed the market and entertained competing offers before it decided to approve the buyout. As will be shown below, the existence of multiple criteria only exacerbates the costs of indeterminacy.

1t The analysis here differs from that in Richard Craswell and John E. Calfee, Deterrence and Uncertain Legal Standards, 2 J L Econ \& Org 279 (1986), and Steven Shavell, Economic Analysis of Accident Law 79-83, 93-97 (Harvard 1987). These models assume that the probability of liability for any choice of behavior is common knowledge and preferences are uniform. See Craswell and Calfee, $2 \mathrm{JI}$ Econ \& Org at 281. They show that under this assumption, legal uncertainty typically results in overdeterrence, which can be corrected either by making the legal standard less exacting or by reducing the sanction. Legal uncertainty still entails a cost because it exposes individuals to costly sanctions even when their behavior is optimal. These sanctions may increase when the law becomes more uncertain because at some point greater uncertainty begins to weaken deterrence. This Article relaxes the assumption of uniform expectations and preferences in order to demonstrate an additional cost of uncertainty that is independent of the costliness of sanctions.
} 
some will offer shareholders only a low premium over stock price, while others will offer a high premium. Their different choices may persist notwithstanding their access to the same legal precedents and commentary and despite their knowledge of the choices made by others. ${ }^{15}$ The divergence of their assessments will reflect the degree of indeterminacy in the law. As legal indeterminacy increases, so will disagreement, and so will the variance in individual behavior. No matter how sanctions are set, this will inevitably lead to greater divergence of behavior from the social optimum. ${ }^{16}$

Once we abandon our simple world for the real one in which corporate legal standards involve multiple criteria, the variance in estimates and thus in behavior is likely to be even greater. Disagreement can be considerable, for example, when courts take into account not only price but also the timing of the transaction, the publicity it is given, the tax advantages it confers, the firm's declining performance, or other factors that point to the directors' good faith belief that the shareholders received the best price. ${ }^{17}$ Beliefs are likely to further diverge in the event that another bidder is competing with management to buy the firm. Here the law instructs the board to consider for each bid, among other things, the adequacy and terms of the offer; its fairness and feasibility; the proposed or factual financing of the offer and the consequences of that financing; questions of illegality; the impact of the bid on other constituencies, provided that it bears some reason-

\footnotetext{
15 See David M. Kreps, A course in microeconomic theory 111, 370 (Princeton 1990) (arguing that equally informed individuals may have different predictions concerning uncertain future events); Stephen Morris, The Common Prior Assumption in Economic Theory, 11 Econ \& Phil 227 (1995) (same). The possibility that equally informed individuals will hold different beliefs concerning potential liability is standard in legal scholarship. See, for example, Steven Shavell, The Fundamental Divergence between the Private and the Social Motive to Use the Legal System, $26 \mathrm{~J}$ Legal Stud 575, 602 (1997); Richard A. Posner, An Economic Approach to Legal Procedure and Judicial Administration, $2 \mathrm{~J}$ Legal Stud 399, 423-26 (1973).

${ }^{18}$ The analysis here employs a similar logic to that in Lucian Arye Bebchuk and Louis Kaplow, Optimal Sanctions When Individuals Are Imperfectly Informed about the Probability of Apprehension, $21 \mathrm{~J}$ Legal Stud 365 (1992). Bebchuk and Kaplow study uncertainty concerning the probability of apprehension. Omri Ben-Shahar uses a similar framework to study uncertainty concerning the severity of sanctions. See Omri BenShahar, Playing Without a Rulebook: Optimal Enforcement When Individuals Learn the Penalty Only by Committing the Crime, 17 Intl Rev I \& Econ 409 (1997).

1 See, for example, Barkan v Amsted Industries, Inc, 567 A2d 1279, 1288 (Del 1989) (using the standards listed above). Other criteria will likely apply as well. For instance, the court will also consider whether the board effectively canvassed the market for alternative offers before approving the buyout and whether all material facts were disclosed to shareholders when the buyout was presented for their approval. See Braunschweiger $v$ American Home Shield Corp, 15 Del J Corp L 997, 1008-09, 1011 (Del Chanc 1989); In re Fort Howard Corp, 14 Del J Corp I 699, 720, 724-25 (Del Chanc 1988).
} 
able relationship to general shareholder interests; the risk of nonconsummation; the basic shareholder interests at stake; the bidder's identity, prior background, and other business venture experiences; and the bidder's business plans for the corporation and their effects on shareholder interests. ${ }^{18}$

Even if all corporate fiduciaries hold the same estimates of their potential liability, differences in their individual preferences will cause their behavior to vary. When the law is determinate, sanctions can be set high enough to deter fiduciaries from undercomplying with legal requirements. And because there is no risk that a sanction will be imposed on fiduciaries who comply with the law, there is no reason for them to overcomply either. By contrast, when the law is indeterminate, the probability of liability is always positive and increases incrementally with movement toward undesirable behavior. Consequently, fiduciaries with lower utility from engaging in the regulated behavior, or higher disutility from sanctions, restrain their behavior more than others. In the management buyout hypothetical discussed earlier, for example, fiduciaries offer premiums over the share price such that their marginal utility from lowering the premium equals their marginal disutility from increasing their legal exposure. As legal indeterminacy increases, the probability of liability becomes less sensitive to changes in premiums, and the premiums offered by any two fiduciaries with different utility functions further diverge. Thus, it is impossible to induce uniform fiduciary behavior.

The divergence of behavior from the social optimum as a result of legal indeterminacy is costly. ${ }^{19}$ Consider the management

${ }^{19}$ See Mills Acquisition Co v Macmillan, Inc, 559 A2d 1261, 1282 n 29 (Del 1989). The list of relevant criteria for contested management buyouts does not end here. It is also relevant, for instance, to evaluate whether the board treated management and other bidders evenhandedly. See id at 1285 .

${ }^{19}$ I assume here that the mean of the distribution representing the legal standard is at the social optimum. Whether judge-made law in general converges with the social optimum is an open question. See, for example, William M. Landes and Richard A. Posner, Adjudication as a Private Good, $8 \mathrm{~J}$ Legal Stud 235 (1979) (concluding that inefficient case law may be resistant to change); George L. Priest, The Common Law Process and the Selection of Efficient Rules, $6 \mathrm{~J}$ Legal Stud 65 (1977) (arguing that over time case law is bound to reach an efficient outcome). In corporate law, the answer should depend on one's view of the effectiveness of state competition in improving the law. See William L. Cary, Federalism and Corporate Law: Reflections Upon Delaware, 83 Yale I J 663 (1974) (arguing that competition is destructive); Ralph K. Winter, Jr., State Law, Shareholder Protection, and the Theory of the Firm, $6 \mathrm{~J}$ Legal Stud 251 (1977) (arguing that competition is constructive). Paul Mahoney argues that the need to clarify the law through litigation arises only when parties learn from the court what behavior is optimal, but not when the court only enforces optimal behavior already known to the parties. See Mahoney, $66 \mathrm{U}$ Chi L Rev at 925-26 (cited in note 3). To my mind, legal clarity is valuable in both situations. Fiduciary duties are designed to compel corporate fiduciaries to behave optimally despite 
buyout hypothetical. Assume again that price is the only criterion for determining the propriety of management buyouts and that a particular premium would be socially optimal in a certain buyout. Because the law does not announce that premium as the threshold of liability, corporate fiduciaries must estimate the threshold based upon past interpretations of the legal standard. Those who underestimate it choose a lower premium, thereby harming shareholders. Those who overestimate it may forgo the buyout altogether to avoid harming themselves. ${ }^{20}$ Consequently, more underpriced than overpriced management buyouts take place in the market, causing stock prices to decline. ${ }^{21}$

Legal indeterminacy also gives rise to risk-bearing costs. In a world of costless monetary sanctions, the disutility to directors and officers from paying damages would not present a social concern. Every dollar they paid in damages would be collected by plaintiffs, keeping social welfare fixed. But sanctions are not costless in the real world because directors and officers may well be risk averse, especially when they stand to lose large amounts of money relative to their personal wealth. ${ }^{22}$ Consequently, every dollar they lose in court is worth more than a dollar to them. ${ }^{23}$ As

their self-serving inclinations. Clarification of the legal standard through litigation is necessary to inform fiduciaries not about the socially optimal behavior-which they may know already-but rather about the behavior required of them by law. Since the legal requirement constrains their behavior, clarifying this requirement will lead their behavior to converge to the mean of the legal standard, which is assumed to be set optimally.

${ }^{20}$ Management buyouts can increase firm value in a number of ways. See Ronald $\mathrm{J}$. Gilson and Bernard S. Black, The Law and Finance of Corporate Acquisitions 404-29 (Foundation 2d ed 1995) (reviewing the literature). Suppose that the firm's current market capitalization is $\$ 70$ million, but that its true value is $\$ 100$ million before the buyout and $\$ 120$ million after the buyout. In the absence of a rule announcing $\$ 100$ million as an adequate offer price, fiduciaries who underestimate the adequate price will offer shareholders less than that amount. Fiduciaries who overestimate it will proceed with the buyout only if they believe the adequate price to be lower than $\$ 120$ million.

${ }^{21}$ The problem is similar to that analyzed in Lucian Arye Bebchuk and Marcel Kahan, The "Lemons Effect" in Corporate Freeze-Outs, in Randall K. Morek, ed, Concentrated Corporate Ownership (Chicago forthcoming 1999), available online at <http://nberws.nber.org/ papers/w6938> (visited Apr 12, 1999). The general framework of the problem is set out in George A Akerlof, The Market for "Lemons": Quality Uncertainty and the Market Mechanism, 84 Q J Econ 488 (1970). This result is not unique to management buyouts. It is essentially the same in freezeout mergers, self-dealing, usurpation of corporate opportunities, or other transactions prone to managerial conflict of interest.

${ }^{22}$ See Frank H. Easterbrook and Daniel R. Fischel, Optimal Damages in Securities Cases, 52 U Chi L Rev 611, 640-41 (1985); Alan O. Sykes, The Economics of Vicarious Liability, 93 Yale L J 1231, 1235-36 (1984).

${ }^{2}$ See Polinsky and Shavell, $69 \mathrm{Am}$ Econ Rev at 888 (cited in note 5). Risk-bearing costs may be even higher because plaintiffs' attorneys bear risk as well and are limited in their ability to diversify that risk by forming large law firms that can handle numerous suits. See John C. Coffee, Jr., Understanding the Plaintiffs Attorney: The Implications of Economic Theory for Private Enforcement of Law Through Class and Derivative Actions, 86 Colum L Rev 669, 705-11 (1986). Every dollar they receive in fees may thus be worth 
legal indeterminacy increases and the variance of trial outcomes grows, so too does this loss. ${ }^{24}$ Although initially borne by corporate fiduciaries, the cost of liability risk does not rest with them. At least in part, it is passed on to shareholders in a number of ways. First, it manifests itself in the escalation of executive and board compensation, as well as in the refusal of able individuals to serve on boards. ${ }^{25}$ Second, directors and officers may spend large amounts of shareholder money on expensive legal advice in order to minimize their risk. ${ }^{26}$ Third, it provokes excessive caution in business decisionmaking, which is particularly problematic because very little can be done to prevent it. Even ex ante compensation for bearing liability risk fails, because officers and directors will still try to reduce the risk ex post by being overly cautious. ${ }^{27}$

\section{B. Low and Frequent Sanctions as a Response to Indeterminacy}

Classic deterrence theory treats the severity of sanctions and the frequency of enforcement as alternative policy tools for regulating behavior. ${ }^{28}$ Legal sanctions force individuals contemplating undesirable behavior to weigh their potential liability against their private benefit from that behavior. They will engage in the controlled activity only to the extent that their private benefit exceeds their expected disutility from liability (which equals their disutility from the possible sanctions multiplied by the probability of incurring the sanctions).$^{29}$ In principle, numerous combina-

\footnotetext{
less than a dollar to them.

${ }^{24}$ This analysis evaluates conservatively the increase in risk-bearing costs as a result of greater uncertainty. In practice, risk-bearing costs increase even more because at some point greater uncertainty begins to reduce deterrence, and so sanctions must increase in order to keep the mean managerial behavior from shifting. See Craswell and Calfee, $2 \mathrm{~J} \mathrm{~L}$ Econ \& Org at 298-99 (cited in note 14).

${ }^{25}$ See Michael Bradley and Cindy A. Schipani, The Relevance of the Duty of Care Standard in Corporate Govemance, 75 Iowa L Rev I, 35 n 219 (1989) (collecting numerous news reports documenting the resignation of directors in response to unavailability of liability insurance in the 1980s).

${ }^{26}$ See Kaplow, 42 Duke I J at 605 (cited in note 8) (arguing that risk-averse individuals avail themselves of legal advice to reduce the uncertainty that open-ended standards entail).

${ }^{27}$ See Reinier H. Kraakman, Corporate Liability Strategies and the Costs of Legal Controls, 93 Yale L J 857, 865 (1984).

${ }^{23}$ See Becker, 76 J Pol Econ 169 (cited in note 5).

2 Because damages in fiduciary lawsuits are largely covered by shareholder-funded insurance and indemnification, the purpose of these suits cannot be to compensate shareholders for damages caused by corporate fiduciaries, but rather to deter wrongdoing and develop the law. See Donald E. Schwartz, In Praise of Derivative Suits: A Commentary on the Paper of Professors Fischel and Bradley, 71 Cornell L Rev 322, 327 (1986); Coffee, 86 Colum I Rev at 692-93 (cited in note 23).
} 
tions of sanction and enforcement levels can achieve the same deterrent effect. Monetary sanctions, for example, can be as low as a few pennies or as high as the entire personal wealth of defendants. The rate of law enforcement can vary from bringing to court a few wrongdoers to bringing to court as many as can be detected. But while frequent enforcement and severe sanctions are in principle alternative ways to deter wrongdoers, in practice enforcement is often more costly. As long as sanctions are less costly than enforcement, optimal enforcement policy combines the highest sanction defendants can bear with low enforcement. While the level of deterrence remains unchanged, it is achieved at minimum cost.

The indeterminacy that characterizes corporate law, however, introduces another variable into the pure deterrence calculus and alters its result. Given indeterminacy, enforcement serves not only as a deterrent, but also as a means to clarify the law. Enforcement is the engine for generating case law. As decided cases accumulate, fiduciary standards become clearer. Every court decision applies the standards to a specific factual scenario and sheds additional light on their meaning. ${ }^{30}$ This does not mean that indeterminacy ever disappears. The elucidation of corporate law through adjudication is a never-ending process. New uncertainties quickly replace resolved ones, as the dynamic nature of the corporate world constantly poses new legal questions to be answered. ${ }^{31}$ While it is futile to hope for the elimination of legal uncertainty in a standard-based regime, a steady flow of lawsuits is rather necessary to keep certainty from decreasing. ${ }^{32}$

\footnotetext{
${ }^{30}$ See note 8 and accompanying text. For an illustration of the process by which precedents make concrete standards in the context of management buyouts, see Edward B. Rock, Saints and Sinners: How Does Delaware Corporate Law Work?, 44 UCLA L Rev $1009,1022-63$ (1997). The analysis here extends previous scholarship that acknowledged the value of litigation as a means of reducing uncertainty. That literature argued that infrequent law enforcement may lead individuals to miscalculate both the level of enforcement and the magnitude of sanctions. See Bebchuk and Kaplow, $21 \mathrm{~J}$ Legal Stud at 366 (cited in note 16); Ben-Shahar, 17 Intl Rev L \& Econ at 410 (cited in note 16). But even if corporate fiduciaries have accurate information on the level of enforcement and the magnitude of sanctions, litigation can be cost effective as a means of informing them about the very content of their legal obligations to shareholders.

${ }^{31}$ See Landes and Posner, $19 \mathrm{~J}$ L \& Econ at 263 (cited in note 8) (arguing that precedents depreciate over time and become obsolete).

${ }^{32}$ The incremental process by which litigation develops the law is consistent with the failure of some empirical studies to discern any effects of major appellate decisions handed down in Delaware on share price of Delaware firms. See Elliott J. Weiss and Lawrence J. White, Of Econometrics and Indeterminacy: A Study of Investors' Reactions to "Changes" in Corporate Law, $75 \mathrm{Cal}$ L Rev 551 (1987); Bradley and Schipani, 75 Iowa L Rev at 59 (cited in note 25). Delaware's reliance on legal standards makes it very difficult to gener-
} 
Naturally, not all cases add the same amount of certainty to the system. In fact, most cases settle without proceeding to final judgment. But while this may seem to undercut the value of relying on enforcement to reduce uncertainty, its effect is not as substantial as it first appears. First, all settlements of shareholder lawsuits must be approved by the court. In Delaware, this process involves a close judicial inspection of the proposed settlement on its merits. ${ }^{33}$ While possibly less detailed and authoritative than court decisions after full trial, written opinions in settlement proceedings do serve to clarify the law. ${ }^{34}$ Even written opinions from earlier trial stages can provide important legal guidance. Settlements often follow denial of motions to dismiss or motions for summary judgment, in which the court opines about the strength of the case and sets valuable guidelines for future behavior. ${ }^{35}$ Second, both decided cases and settled cases can reduce legal uncertainty indirectly by honing the skills of judges and attorneys. ${ }^{36}$ Experienced judges apply legal standards in a more principled manner than do uninitiated judges. Veteran trial attorneys predict legal outcomes better than do unseasoned ones. Even cases that settle mid-trial contribute to those skills and thus are valuable. Third, while settlements may be less effective than full trials in clarifying the law, they are also less expensive: they obviate the need to hear witnesses, involve lower damage

alize from individual court decisions to predict the future course of the law. Only the aggregate of numerous precedents indicates legal trends. See Rock, 44 UCLA L Rev at 1098 (cited in note 30); Merritt B. Fox, The Role of the Market Model in Corporate Law Analysis: A Comment on Weiss and White, 76 Cal L Rev 1015, 1035-38 (1988); William T. Allen, Law and Markets as Social Products, in Arnold W. Sametz and James L. Bicksler, eds, The Battle for Corporate Control 148-49 (Irwin 1991). The expectation that this aggregate will continue to grow is already reflected in share prices.

"See, for example, Zapata Corp v Maldonado, 430 A2d 779, 788 (Del 1981).

* See, for example, Barkan v Amsted Industries, Inc, 567 A2d 1279 (Del 1989); Polk v Good, 507 A2d 531 (Del 1986); In re Caremark Ine Derivative Litigation, 698 A2d 959 (Del Chanc 1996); In re MAXXAM, 659 A2d 760 (Del Chanc 1995); In re Vitalink Communications Corp Shareholders Litigation, 17 Del J Corp I 1311 (Del Chanc 1991); Stepak v Tracinda Corp, 15 Del J Corp L 750 (Del Chanc 1989); In Re Maxxam Group, Inc Stockholders Litigation, 13 Del J Corp L 324 (Del Chanc 1987).

${ }^{3 s}$ See, for example, Aronson $v$ Lewis, 473 A2d 805 (Del 1984); Zapata, 430 A2d 779. See also Rock, 44 UCLA L Rev at 1097 (cited in note 30) (arguing that fiduciary duty law evolves incrementally even through court decisions that do not produce a legal rule).

see Kamar, 98 Colum L Rev at 1935 (cited in note 4) (discussing the maintenance of judicial proficiency through adjudication); Colin F. Camerer, Progress in Behavioral Game Theory, $11 \mathrm{~J}$ Econ Persp 167 (1997) (illustrating the point in the context of game theory); Alan Schwartz, Proposals for Products Liability Reform: A Theoretical Synthesis, 97 Yale L J 353, 381-82 (1988) (reviewing the literature on learning to assess risk through experience); Jennifer Arlen, Comment: The Future of Behavioral Economic Analysis of Law, 52 Vand L Rev 1765, 1784 (1998) (arguing that specialized lawyers improve the accuracy of their risk assessments by learning from their mistakes). 
awards, and induce fewer litigant expenditures. Hence, particularly when final decisions are scarce, the value of each additional decision may justify the cost of the suits that settle. ${ }^{37}$

In addition to inducing optimal behavior by clarifying the law, frequent enforcement combined with low sanctions also reduces risk-bearing costs. Legal indeterminacy creates an omnipresent risk of liability. ${ }^{38}$ While corporate fiduciaries can limit their legal exposure by altering their behavior, they can never eliminate it. They do not know whether they will be sued, and cannot foretell the outcome of a suit if it is brought. To the extent that corporate fiduciaries are risk averse, their disutility from this uncertainty exceeds their expected sanctions and thus constitutes a deadweight loss to society. This loss can be mitigated by reducing sanctions below the maximum that corporate fiduciaries can bear while increasing the frequency of enforcement. ${ }^{39}$ Uncertainty is lower when its only source is legal indeterminacy than

${ }^{\pi}$ See Romano, $7 \mathrm{JL}$ Econ \& Org at 85 (cited in note 3). I discuss below the costs of enforcement and possible ways of discouraging settlements. See Parts III.A and III.C.

* Most state laws permit limitation or elimination of directorial (but not managerial) personal liability for monetary damages for breach of the duty of care. See Olson and Hatch, Director and Officer Liability § 1.07[1]-[2] at 1-37-1-48 (cited in note 1); American Law Institute, Principles of Corporate Governance: Analysis and Recommendations $\$ 7.19$ at 256-58 (1994). The Delaware statute, for example, allows shareholders to exculpate directors from certain types of liability in the certificate of incorporation. See $8 \mathrm{Del}$ Code Ann $\S 102(b)(7)$ (1991). None of these statutes, however, applies to the duty of loyalty or to various other exceptions. Because the distinction between the duty of loyalty and the duty of care is not always clear, the primary effect of these statutes is to encourage plaintiffs to couch claims for monetary damages in terms of one of the statute's exceptions. See, for example, Dennis J. Block, Nancy E. Barton, and Stephen A. Radin, The Business Judgment Rule: Fiduciary Duties of Corporate Directors 110 (Prentice Hall 4th ed 1993), and the sources cited therein. For a recent example of how such mixed claims, combined with disclosure claims, can survive a motion for summary judgment despite the existence of exculpation provisions in the certificate of incorporation, see Emerald Partners $v$ Berlin, 726 A2d 1215 (Del 1999).

30 Reducing sanctions while increasing the rate of enforcement can also alleviate liability risk when the law is clear but some individuals, whose private gain from violating the law exceeds the expected sanction (which is set equal to the social cost of their behavior), are not deterred and face uncertain enforcement. See Polinsky and Shavell, $69 \mathrm{Am}$ Econ Rev 880 (cited in note 5). Legal indeterminacy, however, is an additional source of liability risk, which constitutes an independent reason to reduce sanctions and increase the rate of enforcement. Note that this explanation differs from the standard treatment of liability insurance and indemnification as a response to legal uncertainty. Previous commentators have noted that director and officer liability insurance and indemnification can shift liability risk from risk-averse fiduciaries to diversified shareholders. See Parry and Parry, 58 J Risk \& Ins 30 (cited in note 7); Kraakman, 93 Yale L J at 864-67 (cited in note 27) (arguing that insurance for acts of management serves to shift liability risk from managers to shareholders). Risk shifting, however, requires that managerial compensation reflect the expected cost of liability. This requirement is not borne out in the existing empirical evidence. See note 3 . The decoupling rationale does not imply a similar requirement. Rather than shifting the risk to shareholders, decoupling reduces the risk fiduciaries bear by making sanctions more frequent and less severe. 
when it is also unknown who will fall within the sample of corporate fiduciaries that are sued. Since the two risks are not negatively correlated, reducing one of them by increasing the occurrence of litigation lowers overall liability risk. The degree to which enforcement should be raised and sanctions reduced depends on the level of legal indeterminacy. Because risk-bearing costs are higher when legal indeterminacy is greater, the benefit of reducing sanctions and increasing enforcement is also greater in this context.

\section{ACHIEVING OPTIMAL ENFORCEMENT THROUGH DECOUPLED LIABILITY}

Having identified how a combination of frequent lawsuits and lenient sanctions can serve the socially valuable goals of increasing determinacy in corporate law and reducing legal risk, the discussion now turns to the implementation of this enforcement policy. The central difficulty is similar to that presented by the traditional policy of combining maximum sanctions and minimum enforcement: The amount of damages that optimally deters defendants' misconduct will not necessarily prompt the proper level of litigation by plaintiffs. The solution in both cases is to decouple liability - to separate the damages defendants pay from the awards plaintiffs collect-so that sanctions and enforcement can be adjusted separately. In corporate law, where frequent enforcement and low sanctions are desirable, insurance and indemnification performs the necessary decoupling by allowing plaintiffs to collect more than what defendants pay.

\section{A. Standard and Reverse Decoupling}

Consider first the traditional policy of combining minimal enforcement with maximal sanctions. Achieving this is straightforward in criminal law, where enforcement is conducted by the government. The intensity of law enforcement in this case is a matter of prosecutorial discretion, and the magnitude of sanctions can be controlled by legislation. Clearly, the government can adjust one without altering the other.

It is more difficult to pursue a similar enforcement policy in civil law because the frequency of enforcement is directly controlled by the magnitude of damage awards, and so imposing high monetary sanctions on defendants also induces plaintiffs to sue. The solution to this problem is to break the tie between the magnitude of sanctions and the level of enforcement, and to award plaintiffs an amount of money different from what defendants 
pay. ${ }^{40}$ While defendants should pay as much as they can afford, plaintiffs should receive whatever is needed to induce them to sue frequently enough to create the desired deterrent effect. Although in principle plaintiffs might need to receive either less or more than what defendants pay, the literature treats the latter possibility as more theoretical than real. The focus on awarding plaintiffs less than what defendants pay is not surprising. It follows from the assumption that defendants should always pay the highest damages possible. The only reason to award plaintiffs more than that amount is that failing to do so would result in insufficient litigation. The circumstances in which awarding plaintiffs the entire personal wealth of defendants would result in too little litigation are not common.

Just like the combination of low enforcement and high sanctions, the combination of frequent enforcement and lenient sanctions can readily be achieved when law enforcement is entrusted to public authorities. Public enforcers are not motivated by the pecuniary profits they may gain from litigation, but rather by policy goals and institutional incentives. Indeed, criminal law enforcement is based almost exclusively on sanctions that do not directly benefit law enforcement authorities. It is more difficult to combine lenient sanctions with frequent enforcement, however, when enforcement is entrusted to individual plaintiffs. Unlike paid prosecutors, private plaintiffs will file suit only if they expect to collect damages high enough to recover their expenses. If damages were paid exclusively by defendants, any increase in enforcement could be brought about only by an increase in sanctions. ${ }^{41}$

Insurance and indemnification can provide a solution to the problem by enabling courts to compensate plaintiffs and their at-

${ }^{\text {to }}$ See Polinsky and Che, 22 RAND J Econ 562 (cited in note 6); Warren F. Schwartz, An Overview of the Economics of Antitrust Enforcement, 68 Georgetown L J. 1075, 1092-96 (1980).

"The analysis here does not apply to suits for injunction brought by bidders against the boards of target companies in the course of battles for corporate control, since bidders are sufficiently motivated to sue by the prospect of acquiring the target. Indeed, courts deny such plaintiffs reimbursement for their trial expenditures precisely for this reason. See In re Dunkin' Donuts Shareholders Litigation, 16 Del J Corp L 1443, 1458-61 (Del Chanc 1990). However, the law on hostile takeovers can also develop through suits for an injunction or damages brought by unaffiliated shareholders. See, for example, Gilbert $v$ El Paso Co, 575 A2d 1131 (Del 1989); Citron v Fairchild Camera and Instrument Corp, 569 A2d 53 (Del 1989); Moran v Household Intermational, Inc, 500 A2d 1346 (Del 1985); Pogostin v Rice, 480 A2d 619 (Del 1984); Tomczak v Morton Thiokol, Inc, 16 Del J Corp I 924 (Del Chanc 1990); In re RJR Nabisco, Inc Shareholders Litigation, 14 Del J Corp L 1132 (Del Chanc 1989). In these cases, the prospect of gaining control over the firm as an incentive to sue is absent, and so litigation depends on compensating plaintiffs for their expenditures. 
torneys for the considerable expenses of corporate litigation without imposing the full cost of the litigation on defendants as a sanction. ${ }^{42}$ In contrast to the situation where maximum sanctions are optimal, however, in the present context it is easy to see the need for awarding plaintiffs more than what defendants pay. It is more likely that plaintiffs will face weak incentives to sue when defendants pay far less than they can afford. ${ }^{43}$

Although insurance and indemnification provides complete protection only from duty of care liability, its decoupling effect spans the spectrum of fiduciary duties. Insurance policies ordinarily exclude from coverage the receipt of personal profit or advantage to which to the insured was not legally entitled..$^{44}$ But not all breaches of fiduciary duty other than the duty of care fall under this exclusion. For example, a dominated board that approves managerial self-dealing in which it has no direct interest may be in breach of its duty of loyalty, and yet be insured. Similarly, both management and the board may run afoul of the duty of loyalty by not disclosing material information relevant to the approval of otherwise fair self-dealing, and still be covered by insurance.

Furthermore, the line between loyalty and care issues is often murky, particularly at the early stage when the claim is filed. It is commonplace for plaintiffs to assert facts that give rise to both claims at once in order to avoid dismissal due to exculpation statutes. ${ }^{45}$ Insurers routinely cover settlements of such mixed,

\footnotetext{
12 One indication of the cost of bringing fiduciary claims can be found in a study of the fifteen management buyout cases brought in Delaware between 1981 and 1990. In these cases, plaintiffs' attorneys were awarded a total of \$17.2 million. See Rock, 44 UCLA L Rev at 1094, 1099 (cited in note 30). A sample of twenty-nine derivative actions brought from the late 1960s through 1987 against directors and officers of public corporations provides a more conservative estimate. Attorneys' fees in this sample averaged \$394,771. See Roberta Romano, The Shareholder Suit: Litigation Without Foundation 27 (Yale Law School Center for Studies in Law, Economics, and Public Policy Working Paper No 130, Mar 1990). Last, fees awarded to plaintiffs' attorneys in ninety-eight settlements of corporate class or derivative actions brought in the Delaware Court of Chancery between July 1, 1989 and December 31, 1991 ranged from $\$ 15,000$ to $\$ 12$ million. In twenty of those cases, the fees awarded exceeded $\$ 1$ million. See Carolyn Berger and Darla Pomeroy, Settlement fever: How a Delaware court tackles its cases, 2 Bus L Today 7, 9 (Sept 1992).

4 Importantly, in addition to defraying the cost of bringing fiduciary claims, insurance and indemnification also defrays the cost of defending these suits, which may be even higher. See Romano, $7 \mathrm{~J} \mathrm{~L} \mathrm{Econ} \mathrm{\&} \mathrm{Org} \mathrm{at} 65$ (cited in note 3); Coffee, 86 Colum L Rev at 701-02 (cited in note 23). In a sample of 154 shareholder fiduciary claims that closed between 1989 and 1998, the average defense cost was $\$ 1.3$ million in addition to the cost of representation by in-house counsel. See Mark W. Larsen, Directors \& Officers Liability Survey: 1998 Results and Historical Trends 28 (unpublished presentation materials) (Tillinghast-Towers Perrin Mar 1999).

" See OIson and Hatch, Director and Officer Liability § 10.06[5][a] at 10-28 (cited in note 1).

${ }^{45}$ Exculpation statutes limit or eliminate directorial liability for breach of the duty of
} 
hard-to-categorize fiduciary claims in order to save the costs of protracted litigation. Indeed, when settlement of the fiduciary claims also releases related securities class actions, the willingness to extend insurance coverage is even greater. The same is true for indemnification. State laws that permit indemnification typically restrict it to situations that do not raise loyalty issues. Settling the claim, however, avoids determination of whether the restriction applies. Thus, even breaches of fiduciary duty that after trial may be excluded from coverage are potentially covered ex ante for purposes of calculating expected liability.

Notably, the effectiveness of insurance and indemnification as a decoupling mechanism owes itself to the notorious agency relationship between shareholders and the attorneys who represent them in court. ${ }^{46}$ Because the attorneys do not share the cost of insurance and indemnification, payment from that source is a net gain for them and an incentive to sue. Were the interests of attorneys aligned with those of the shareholders they represent, attorneys would also consider the cost of insurance and indemnification and, consequently, would not regard recovery from insurance and indemnification as an incentive to sue. The presence of transaction costs would always render the cost of insurance and indemnification higher than their benefit, and attorneys internalizing both would refrain from filing suits. ${ }^{47}$

care only. See note 38 .

${ }^{40}$ Insurance and indemnification covers not only awards paid to shareholders but also attorney fees. See Goodrich v E.F. Hutton Group, Inc, 681 A2d 1039 (Del 1996). This is key to the effectiveness of insurance and indemnification as a tool for decoupling liability because shareholder suits are controlled by attorneys rather than shareholders. See Marcel Kahan and Bruce Tuckman, Special Levies on Punitive Damages: Decoupling, Agency Problems, and Litigation Expenditures, 15 Intl Rev L \& Econ 175 (1995) (arguing that decoupled liability should focus on the incentives of plaintiffs' attorneys when agency concerns are present).

"See Charles J. Goetz, A Vendict on Corporate Liability Rules and the Derivative Suit: Not Proven, 71 Cornell L Rev 344, 348 (1986) (arguing that entrusting derivative litigation to representative plaintiffs presents a credible threat to sue aberrant directors and offcers). Diversified shareholders could theoretically capture the benefits to all firms from lawmaking and sue optimally. Experience with diversified institutional investors indicates, however, that collective action problems tend to chill any shareholder activism the benefits of which are shared by all firms. See, for example, Edward B. Rock, The Logic and (Uncertain) Significance of Institutional Shareholder Activism, 79 Georgetown L J 445, 453-78 (1991); John C. Coffee, Jr., Liquidity Versus Control: The Institutional Investor as Corporate Monitor, 91 Colum L Rev 1277, 1317-28, 1342-45 (1991); Bernard S. Black, Shareholder Passivity Reexamined, 89 Mich L Rev 520, 523 (1990). Furthermore, even if shareholders captured the entire benefit from lawmaking, they would not consider this benefit when making litigation decisions. See Kraakman, Park, and Shavell, 82 Georgetown $\mathrm{L} J$ at $1741,1748,1756 \mathrm{n} 64$ (cited in note 3) (making an analogous argument about the benefit from deterrence). 


\section{B. Insurance and Indemnification Versus State Subsidies to Plaintiffs}

To decouple liability for the purpose of encouraging litigation is essentially to subsidize litigation. In general, subsidies to plaintiffs can come from any source. One possible source can be taxpayer money. Subsidies from this source could take the direct form of awarding supplemental payments to winning plaintiffs or the indirect form of supporting the court system using public funds. ${ }^{48}$ Corporate law does not rely on public funding to subsidize litigation, but rather imposes the cost of litigation on shareholders through the mechanism of liability insurance and indemnification. Firms that use the law more often through their involvement in lawsuits pay higher insurance premiums and spend more on indemnification, thus contributing more to the development of the system.

In principle, imposing this cost on shareholders can be efficient in that it compels them, as consumers of corporate law, to pay for its maintenance. ${ }^{49}$ Whether it is efficient in practice depends on whether the indeterminacy that warrants such maintenance could be avoided. Some indeterminacy is probably inescapable in view of the relational context of the corporate contract..$^{50}$ But does the current level of indeterminacy in the law represent no more than this minimum? I remain skeptical. One point is clear, however. The competition among states in providing corporate law gives no assurance that the current level of indeterminacy in state law is optimal. Since the market for corporate law is imperfectly competitive, it can easily sustain excessive indeterminacy. ${ }^{51}$ If indeterminacy in corporate law is too high, shareholders who internalize its cost shoulder an unnecessary burden that their economic activity did not create. And if that is the case,

45ee Polinsky and Che, 22 RAND J Econ at 563 (cited in note 6) (suggesting supplemental payments); Landes and Posner, $19 \mathrm{~J} \mathrm{~L} \mathrm{\&} \mathrm{Econ} \mathrm{at} 272$ (cited in note 8) (suggesting government support of the court system).

49 Previous scholarship has acknowledged the value of imposing the state's litigation costs on plaintiffs. See Shavell, $26 \mathrm{~J}$ Legal Stud at 587 (cited in note 15); Rex E. Lee, The American Courts as Public Goods: Who Should Pay the Costs of Litigation?, 34 Cath U L Rev 267 (1985); Richard A. Posner, The Federal Courts: Crisis, and Reform 136 (Harvard 1985). Director and officer liability insurance and indemnification goes further by imposing the full costs of developing and maintaining corporate law on its users.

so See Klausner, $81 \mathrm{Va} \mathrm{L}$ Rev at 775-76 \& n 60 (cited in note 8). Independent of whether indeterminacy could be avoided, some argue that it can in fact be helpful in preventing management from circumventing the law. See John C. Coffee, Jr., The Future of Corporate Federalism: State Competition and the New Trend Toward De Facto Federal Minimum Standards, 8 Cardozo L Rev 759, 766 (1987).

sl See Kamar, 98 Colum I Rev at 1919-23 (cited in note 4). See also the discussion in Part III.E of this Article. 
even if insurance and indemnification is an efficient response to indeterminacy, it can at most be a second-best solution, inferior to the adoption of more determinate law. Whether current insurance and indemnification practices are in fact such an efficient response is a question I shall turn to next.

\section{Is DECOUPLING EFFICIENT IN PRACTICE?}

That liability insurance and indemnification can be desirable given indeterminate law does not mean that it is so as practiced today. Among the relevant considerations in this regard are the cost of enforcement, the possibility that legal uncertainty in itself spurs enough litigation, the extent to which insurance and indemnification induces settlements, and the adequacy of deterrence under the current legal regime. Below I analyze each of these factors.

\section{A. The Cost of Enforcement}

The analysis thus far has presented only the benefits of reducing sanctions and increasing enforcement of corporate law. Optimal enforcement, however, balances benefits against costs. Specifically, enforcement should be increased only insofar as its marginal cost is lower than its marginal benefit. ${ }^{52}$ In principle, this optimum can be anywhere. On one extreme, if the marginal cost of enforcement is always higher than its marginal benefit in clarifying the law and reducing liability risk, the optimum will be reached when enforcement is minimal. In this case, there will be no advantage in decoupling liability through insurance and indemnification. On the other extreme, if the marginal cost of enforcement is always lower than its marginal benefit, the optimum will be reached when enforcement is maximal. In this case, liability should be decoupled completely, resulting in numerous lawsuits and minuscule participation of defendants in payment of damages.

\footnotetext{
52 Naturally, increased enforcement produces both meritorious and nonmeritorious lawsuits. See Mahoney, $66 \mathrm{U}$ Chi L Rev at 927-28 (cited in note 3). However, either type of lawsuit develops the law, and both reduce liability risk. See, for example, Rock, 44 UCLA I Rev at 1098 (cited in note 30) (showing that because even defense victories are valuable in clarifying the law, fees for plaintiff victories should be sufficiently high to motivate bringing cases that might be lost). It would be ideal to increase only the number of meritorious lawsuits, but to the extent that nonmeritorious lawsuits are filed due to plaintiffs' misconception of the legal standard, selective encouragement of only meritorious lawsuits is impossible. Nevertheless, requiring defendants to contribute to settlement payments could motivate them to defend their position more vigorously and so discourage nonmeritorious lawsuits. See text accompanying notes 62-64.
} 
The truth is probably somewhere in the middle. Whereas the marginal cost of enforcement is initially lower than its marginal benefit, this relationship eventually reverses. The social optimum is located where the two are equal. At this point, more than the minimum number of suits is brought, and defendants personally bear more than the minimum amount of sanctions. The logic behind this conjecture is twofold. First, the marginal cost of enforcement likely increases as enforcement increases. Law enforcement requires an initial fixed investment in legal infrastructure. The basic investment in establishing a court system and legal services is the same whether few or many suits are filed thereafter. After the initial investment has been made, the marginal cost associated with any additional suit is relatively low. The cost to a trained judge of handling two lawsuits is not much higher than the cost of handling one. Similarly, a lawyer with an established corporate practice can litigate a second lawsuit without having to reacquire the legal knowledge he acquired to litigate the first. However, the marginal cost of enforcement is not constant. Because the least costly suits are brought first, the cost of litigation per suit increases as more suits are brought. ${ }^{53}$ While initially low, the marginal cost of enforcement gradually escalates, and may eventually equal the benefit from further increases in enforcement.

Second, the marginal benefit from enforcement is likely to decrease as enforcement increases. Consider first the value of enforcement as a means of clarifying the law. When the level of litigation is low, any additional lawsuit reduces legal uncertainty, both by producing decisions and by training judges and lawyers. As cases accumulate, however, the contribution to legal certainty made by each additional case diminishes. The probability that a new case will address an unanswered question decreases, as existing case law is likely to address commonly encountered scenarios.

The marginal benefit from reducing risk-bearing costs should also decline as enforcement increases. Insofar as enforcement reduces legal uncertainty, high levels of enforcement correlate with

\footnotetext{
ss Compare Bebchuk and Kaplow, $21 \mathrm{~J}$ Legal Stud at 367 (cited in note 16). The argument in the text assumes that the increase in the marginal cost of enforcement outweighs any decrease in that cost due to economies of scale. In fact, it is enough to assume that even if economies of scale are initially substantial, they gradually decline. This assumption is very plausible. As litigation increases, lawyers and judges gain expertise, and the law becomes less uncertain and hence less costly to litigate. But all these effects, which reduce the marginal cost of enforcement, become less significant as the volume of litigation continues to grow.
} 
low levels of uncertainty. Low levels of legal uncertainty in turn impose only moderate risk-bearing costs on corporate fiduciaries, and hence there is less utility in further reducing these costs. ${ }^{54}$ Furthermore, the low sanctions that accompany high levels of enforcement render individual managerial risk-bearing costs relatively insensitive to additional increases in enforcement and decreases in sanctions.

\section{B. Legal Uncertainty as an Insufficient Inducement for Litigation}

Having established that legal indeterminacy warrants frequent enforcement with low sanctions, one should still inquire whether insurance and indemnification is necessary to achieve this goal in practice or whether legal uncertainty itself spurs sufficient litigation. Just as uncertainty leads to disagreement between different defendants, the argument would go, it also leads to disagreement between defendants and plaintiffs. This, in turn, results in more disputes proceeding to trial without settling. ${ }^{55} \mathrm{Op}$ timal enforcement may thus be achieved with no need for decoupling. ${ }^{56}$

The question, however, is whether legal indeterminacy alone can induce sufficient litigation. Assuming that damages today are set optimally, they would have to be significantly lower in the absence of insurance and indemnification lest deterrence be too high. Given such low damages, it is far from clear that the propensity to sue would be sufficient. To take an extreme case, if damages were lower than the cost of bringing a suit, no divergence of expectations would suffice to induce litigation. ${ }^{57}$ An indication that decoupling liability through insurance and indemnification is necessary to induce litigation notwithstanding the divergence of litigant expectations due to uncertainty is the relatively low number of fiduciary claims brought today, when both of these factors affect lawsuit filings. All accounts on this matter point to the same conclusion. While figuring prominently in the

s Compare text accompanying notes 26-27.

ss See Robert D. Cooter and Daniel L. Rubinfeld, Economic Analysis of Legal Disputes and Their Resolution, $27 \mathrm{~J}$ Econ Lit 1067, 1092 (1989); Steven Shavell, Suit, Settlement, and Trial: $A$ Theoretical Analysis under Altemative Methods for the Allocation of Legal Costs, 11 J Legal Stud 55, 63 n 36 (1982); Posner, 2 J Legal Stud 399 (cited in note 15).

se See Landes and Posner, $19 \mathrm{~J}$ L \& Econ at 269-72 (cited in note 8) (modeling spontaneous replenishment of depreciated case law as a result of growing legal uncertainty, which triggers litigation).

"See id at 273-74 (arguing that litigation subsidies may be needed to prevent underproduction of precedents when litigants' reservation price is lower than the cost of adjudication). 
media, fiduciary claims are not a frequent event in the life of firms. ${ }^{58}$ In the absence of insurance and indemnification, their frequency would be even lower.

\section{The Pressure to Settle}

Earlier I noted that the misalignment of interest between attorneys and the shareholders they represent makes insurance and indemnification effective for inducing litigation. ${ }^{59}$ However, while self-interest drives attorneys to file suits where shareholders would not, it also leads them to settle many of those suits before they produce socially valuable precedents. ${ }^{60}$ Indeed, it is the very availability of insurance and indemnification that motivates these settlements. Settling a claim relieves both plaintiffs' attorneys and defendants from the hazards of trial. Plaintiffs' attorneys who lose their cases in court receive no compensation for their work. Defendants who are found liable for acts of dishonesty or the receipt of personal profit or advantage to which they were not legally entitled may be neither insured nor indemnified. Settling a claim avoids both of these hazards. ${ }^{61}$

But a high settlement rate is not an inevitable byproduct of insurance and indemnification. Settlements could be discouraged if defendants had to contribute to their payment. ${ }^{62}$ Indeed, defendant participation in payment of settlement awards could also prevent another undesirable effect of liability insurance and

${ }^{88}$ See Romano, $7 \mathrm{~J}$ L Econ \& Org at 59 (cited in note 3) (reporting 139 suits, both in corporate and securities law, against a sample of 535 publicly traded corporations, from the late 1960s through 1987); Rock, 44 UCLA I Rev at 1090-94 (cited in note 30) (contrasting 15 Delaware management buyout cases with 404 leveraged buyouts of public companies in the United States between 1981 and 1990). See also Coffee, 86 Colum L Rev at 723-34 (cited in note 23) (opining that the current volume of shareholder litigation is likely too low).

so See notes $46-47$ and accompanying text.

${ }^{\infty}$ Settlements are certainly valuable in developing the law. See notes 33-37 and accompanying text. However, to the extent that their value is lower than that of trials, they dilute the effectiveness of litigation as a vehicle of lawmaking and should not be encouraged.

See Coffee, 86 Colum L Rev at 714-20 (cited in note 23).

* Alternatively, settlements could be discouraged and trials encouraged if firms were permitted to indemnify fiduciaries for damages and trial expenses even when held liable. Just like mandatory participation of defendants in settlement awards, this would render the choice between settling the claim and proceeding to trial less consequential for defendants. However, compelling defendants to participate in settlement awards is preferable for two reasons. First, it motivates defendants not only to proceed to trial but also to defend their position vigorously and refrain from colluding with plaintiffs. Second, it preserves the deterrent effects of the law, which could be upset by allowing indemnification of defendants who were found liable. Another way of discouraging settlements could be to tax them. However, a tax might fail to discourage settlements because defendants would agree to higher settlement payments, knowing that they are fully covered. 
indemnification, namely the filing of frivolous suits solely for their settlement value. ${ }^{63}$ Plaintiff' attorneys would probably be more selective in bringing suits if they anticipated that defendants would contest them vigorously. For now, however, the desirability of defendants' participation in settlement payments remains a theoretical question. In practice, insurers do not insist on including personal coverage retention in insurance policies because they are equally compensated by company coverage retention. ${ }^{64}$ Similarly, whenever state law permits firms to indemnify defendants, there is no limit on coverage. Mandating a minimum personal coverage retention by law could fill this gap. But, as with any intervention in the market, it is difficult to ascertain what makes for optimal personal coverage retention and, indeed, whether it should be mandated at all. ${ }^{65}$

\section{The Level of Deterrence}

The prevalence of fully covered settlements under current insurance and indemnification practices also raises deterrence concerns. The evidence on this issue is hardly conclusive. On the one hand, it is clear that directors and officers routinely settle fiduciary claims with complete insurance and indemnification coverage. ${ }^{66}$ Most corporations today purchase for their fiduciaries insurance that covers all their losses in suits that cannot be indemnified. Only 5 percent of the insurance policies today include personal coverage retention. ${ }^{67}$ In the absence of evidence showing that fiduciaries' compensation reflects the cost of insurance, ${ }^{68}$ this complete coverage may well result in underdeterrence. On the other hand, both directors and officers face a higher turnover rate

- See id.

4 A 1998 survey finds that 95 percent of the corporations purchasing director and officer liability insurance currently have no personal coverage deductible. The remainder have a flat personal coverage deductible. A few insurance policies require the insured to pay a percentage of the loss that exceeds the flat deductible. "This retention percentage is usually either 0.5 percent or 5 percent, generally limited to the first $\$ 1$ million of loss above the flat deductible, and appears almost exclusively for New York corporations" pursuant to NY Bus Corp Law \$ 726(a)(3), and 11 NY Comp Codes R \& Regs tit 1, § 72 (1998). These data reflect a trend toward eliminating personal coverage deductibles. Towers Perrin Liability Survey at 34 (cited in note 1). See also Olson and Hatch, Director and Officer Liability $\$ 10.06[7][\mathrm{a}]-[\mathrm{b}]$ at 10-43-10-48 (cited in note 1).

os See Randall R. Bovbjerg, Liability and Liability Insurance: Chicken and Egg, Destructive Spiral, or Risk and Reaction?, 72 Tex L Rev 1655, 1675 (1994) (discussing the difficulty regulators have calibrating the optimal level of insurance coverage); Kent D. Syverud, On the Demand for Liability Insurance, 72 Tex L Rev 1629, 1652-53 (1994) (same).

see Romano, $7 \mathrm{~J} \mathrm{~L} \mathrm{Econ} \mathrm{\&} \mathrm{Org} \mathrm{at} 84$ (cited in note 3).

- See note 64 .

See note 3 . 
after having been sued. ${ }^{69}$ Also true, but difficult to quantify, is that fiduciary claims inconvenience directors and officers and harm their reputations. ${ }^{70}$ This disciplining effect is bolstered by the vilifying tone that court decisions often employ when condemning a defendant's conduct. ${ }^{71}$ In a world of rapid information flow and attentive media coverage, these sanctions can be effective. The same is true with respect to court decisions that precede or approve settlements. These decisions also impact defendants' reputations and thus have a deterrent effect. ${ }^{72}$

\section{E. State Competition as a Guarantor of Efficiency}

As the foregoing discussion shows, it would be difficult to measure whether corporate law addresses legal indeterminacy efficiently. First, it is not clear how to determine whether the reliance on open-ended standards is optimal. Second, it is hard to gauge whether current insurance and indemnification practices respond to the resulting uncertainty efficiently.

These hurdles would be avoided if one could identify a market mechanism that ensures optimality with no need of empirical proof. The decision of shareholders to insure and indemnify corporate fiduciaries clearly provides no such assurance. Shareholders of individual firms are not interested in producing precedents for the entire shareholder community, and therefore do not calibrate insurance and indemnification to achieve this goal optimally. But while shareholders cannot be trusted to adopt socially optimal insurance and indemnification practices, perhaps state

See Romano, $7 \mathrm{~J} \mathrm{I} \mathrm{Econ} \mathrm{\&} \mathrm{Org} \mathrm{at} \mathrm{71-80} \mathrm{(cited} \mathrm{in} \mathrm{note} \mathrm{3).} \mathrm{For} \mathrm{a} \mathrm{recent} \mathrm{example} \mathrm{of}$ chief executive officer dismissal following a corporate lawsuit, see In re Louisiana-Pacific Corp Derivative Litigation, 705 A2d 238, 239 (Del Chanc 1997).

${ }^{70}$ See Sanjai Bhagat, James A. Brickley, and Jeffrey L. Coles, Managerial Indemnification and Liability Insurance: The Effect on Shareholder Wealth, $54 \mathrm{~J}$ Risk \& Ins 721, 726 (1987); Coffee, 86 Colum I Rev at 722 (cited in note 23) (arguing that the mere pendency of an action may have various negative consequences for defendants).

$"$ See Rock, 44 UCLA L Rev at 1028-60 (cited in note 30) (analyzing Delaware cases); Melvin A. Eisenberg, Corporate Law, Social Norms, and Belief Systems, 99 Colum L Rev (forthcoming 1999).

${ }^{72}$ See Rock, 44 UCLA L Rev at 1038-39, 1051-53, $1058-59$ (cited in note 30) (citing specific instances). See also William A. Sahlman, Why Sane People Shouldn't Serve on Public Boards, 68 Harv Bus Rev 28, 30 (May-June 1990) (arguing that settling shareholder lawsuits implies culpability and damages a director's reputation); Coffee, 86 Colum $\mathrm{L}$ Rev at 718 (cited in note 23) (arguing that settling shareholder suits may damage the reputation of directors and officers). Some support for the argument that overall deterrence under current corporate law is meaningful can be found in the fact that shareholders in the United States, more than in other countries, keep small holdings in firms with no fear of being exploited by management. See Rafael La Porta, Florencio Lopez-deSilanes, Andrei Shleifer, and Robert Vishny, Law and Finance, $106 \mathrm{~J}$ Pol Econ 1113 (1998). 
competition provides alternative theoretical grounds to believe that the system is efficient. State corporate law, including the law on insurance and indemnification, did not develop in a vacuum. Rather, it developed against the backdrop of states actively competing to attract incorporation by adjusting their laws to the preferences of corporate decisionmakers. The current law that allows most fiduciary claims to settle with full insurance and indemnification coverage is a product of this competition. Whatever can be said about the desirability of the law that state competition produces in general should be applicable here as well.

Unfortunately, the implications of state competition for the efficiency of current insurance and indemnification practices are not much clearer than the implications for other aspects of corporate law. Take, for example, the deterrence issue. Those who view state law as an outcome of destructive competition among states to appease corporate fiduciaries ${ }^{73}$ would likely treat the lack of mandatory participation of defendants in settlement payments as further proof of their claim that the law underdeters directors and managers. Those who trust competition to breed optimal law ${ }^{74}$ might also argue that full insurance and indemnification coverage leaves just the level of deterrence that shareholders want. As far as theory goes, either interpretation may be right. ${ }^{75}$

State competition provides a more definite, but still incomplete, answer to the question whether the law on insurance and indemnification induces optimal production of precedents. Commentators generally agree that an important source of Delaware's appeal is its developed corporate case law and experienced judiciary and bar. ${ }^{76}$ As a general matter, Delaware's desire to maintain

73 See, for example, Cary, 83 Yale L J 663 (cited in note 19).

"See, for example, Winter, $6 \mathrm{~J}$ Legal Stud 251 (cited in note 19).

${ }^{75}$ While either approach is theoretically sound, a hybrid of the two is tenuous. It would be difficult to reconcile a favorable view of competition in corporate law with skepticism about the deterrent value of claims under the law that competition has bred. For criticism of corporate lawsuits by proponents of competition in corporate law, see Romano, $7 \mathrm{~J} \mathrm{~L} \mathrm{Econ} \mathrm{\&} \mathrm{Org} \mathrm{at} 84$ (cited in note 3) (arguing that "shareholder litigation is a weak, if not ineffective, instrument of corporate governance"); Daniel $R$. Fischel and Michael Bradley, The Role of Liability Rules and the Derivative Suit in Corporate Law: A Theoretical and Empirical Analysis, 71 Cornell L Rev 261, 292 (1986) (arguing that the assumption that "liability rules enforced by derivative suits play a fundamental role in aligning the interests of managers and investors" is unsupportable).

${ }^{70}$ See Kamar, 98 Colum L Rev at 1923-27 (cited in note 4). For the comprehensiveness of Delaware case law, see Kahan and Klausner, $83 \mathrm{Va} \mathrm{L} \mathrm{Rev} 713$ (cited in note 8); Klausner, $81 \mathrm{Va} \mathrm{L}$ Rev 757 (cited in note 8); Romano, $1 \mathrm{~J} \mathrm{~L} \mathrm{Econ} \mathrm{\&} \mathrm{Org} \mathrm{at} \mathrm{277-78} \mathrm{(cited} \mathrm{in} \mathrm{note}$ 8). For the expertise of the courts and the bar, see Rochelle C. Dreyfuss, Forums of the Future: The Role of Specialized Courts in Resolving Business Disputes, 61 Brooklyn I Rev 1, 5-8 (1995); William H. Rehnquist, The Prominence of the Delaware Court of Chancery in the State-Federal Joint Venture of Providing Justice, 48 Bus Law 351 (1992). 
its appeal tends to ensure that the high settlement rate under its insurance and indemnification law optimizes precedent production. This assurance, however, is not perfect. First, even assuming that current precedent production is optimal, it may not be achieved at minimum cost. Arguably, if defendants had to participate in settlement payments, their willingness to settle would decline, as would the motivation of plaintiffs to sue. A body of case law comparable to the one existing today could thus be developed at a lower cost. The reason why Delaware fails to do this is likely political. Despite being inefficient for lawmaking, a multitude of lawsuits and settlements benefits the local corporate bar by generating legal fees and reducing the risks of litigation. ${ }^{77}$ Second, in view of the lawyers' interest in settlements, there is no assurance that current precedent production in itself is optimal. Delaware lawyers gain when the rates of both litigation and settlement are higher. Even if a lower settlement rate could accelerate precedent production and lure additional firms and lawsuits to Delaware, the bar may still prefer fewer firms and lawsuits, as long as many of the lawsuits settle.

The final question that needs to be answered in order to determine the overall efficiency of insurance and indemnification is whether the very use of legal standards that rely on litigation is optimal. There is little value in using litigation to address legal indeterminacy if more determinate law could be formulated at a lower cost. As in the case of precedent production, here too it is not obvious that Delaware maintains its preeminence by offering optimally determinate law. Given its dominant position in the market for corporate chartering, Delaware may benefit from offering overly indeterminate standards. Although excessive indeterminacy may reduce the absolute value of Delaware law, Delaware's well-developed system of adjudication allows it to compensate for some of this indeterminacy. And although other states can copy Delaware's law, they cannot easily emulate its adjudicatory experience and keep up with its growing body of case law.

\footnotetext{
${ }^{27}$ See Jonathan R. Macey and Geoffrey P. Miller, Toward an Interest-Group Theory of Delaware Corporate Law, 65 Tex L Rev 469, 513-14 (1987). The argument that current litigation practices do not minimize the cost of lawmaking relies on the assumption that the cost-benefit ratio of settled claims is higher than that of adjudicated claims, and so more adjudicated claims out of fewer filings could develop the law at a lower cost. In fact, the interest group theory can support a similar argument without making any assumption about costs using a revealed preference reasoning. That is, one can infer that the current system of lawmaking is not the cheapest possible from the fact that this system has developed in a state whose influential bar is interested in maximizing profits from legal services.
} 
Consequently, maintaining indeterminate standards may further entrench Delaware as the corporate chartering leader. ${ }^{78}$

\section{CONCLUSION}

The rationale this Article offers for director and officer liability insurance and indemnification relies on the value of corporate litigation as a public good. ${ }^{79}$ The benefit of corporate litigation in clarifying the law accrues to all firms at once. Because neither shareholders of individual firms nor attorneys suing on their behalf can capture this benefit, neither has sufficient incentives to sue unless compensated to an extent that might overdeter defendants. Insurance and indemnification addresses this market failure through reverse decoupling, which allows courts to compensate plaintiffs for their litigation expenditures without imposing the full cost on defendants.

But to identify the manner in which director and officer insurance and indemnification responds to indeterminacy in corporate law is not to conclude that the existing system is efficient. Shareholders of individual firms subsidize damage awards not because it is efficient for the shareholder community as a whole, but because of the need to recruit able directors and officers and encourage risk-taking. ${ }^{80}$ There is therefore no reason to expect shareholders to enter into socially optimal insurance and indemnification contracts with corporate fiduciaries. In particular, shareholders may well protect fiduciaries from more liability than is necessary to achieve the goals of decoupling. ${ }^{81}$ Moreover, the existence of a competitive insurance market does not guarantee that insurance contracts are socially optimal. All it guarantees is that insurance prices are actuarially fair for the coverage firms select.

${ }^{18}$ See Kamar, 98 Colum L Rev 1908 (cited in note 4).

79 See Romano, $7 \mathrm{~J} \mathrm{~L}$ Econ \& Org at 85 (cited in note 3); Rock, 44 UCLA L Rev at 1020 (cited in note 30); Frank H. Easterbrook and Daniel R. Fischel, The Economic Structure of Corporate Law 34-35 (Harvard 1991). For discussion of precedent as a public good in general, see Richard A. Posner, Economic Analysis of Law 567 (Aspen 5 th ed 1998).

${ }^{s o}$ See, for example, Louis Harris and Associates, Outside Directors and the Risks They Face-III 43 (1998) (reporting survey results according to which 89 percent of the outside directors of Fortune 1000 firms say that inadequate or no liability insurance would be a major barrier to joining a board).

" Shareholders of individual firms do internalize the benefits from reducing the liability risk that directors and officers of those firms bear, and so insurance and indemnification may be socially optimal for achieving this goal. But the benefits from developing the law are shared by the entire shareholder community, and should not affect the decision of shareholders of individual firms to provide fiduciaries with insurance and indemnification. 
While the absence of proper private incentives to set insurance and indemnification coverage optimally may warrant regulation, it is difficult to determine what regulation, if any, is best. The discussion above demonstrates that computing the optimal regulation directly involves such elusive variables as the level of deterrence, the incentives to sue in the absence of decoupling, and the net social gain from case law. Theoretically, the results of the competition among states in attracting incorporation could be the key to the answer. These results are fairly clear. New York law mandates the inclusion only of nominal personal coverage retention provisions in director and officer insurance policies. Delaware law does not go even that far. ${ }^{82}$ And no state limits the extent of indemnification coverage when indemnification is permitted. However, how to interpret these results is unclear. The bare fact that Delaware maintains its preeminence in the market for corporate chartering while allowing most fiduciary claims to settle with full insurance and indemnification coverage is neutral with respect to determining whether deterrence in that state is optimal. It can be squared both with the view that Delaware law is popular thanks to tailoring deterrence to fit shareholder needs and with the view that Delaware law unduly shelters aberrant fiduciaries from liability. Nor does state competition guarantee that Delaware law optimizes precedent production. Although Delaware as a state can benefit from developing case law through litigated cases, its bar can benefit from settlements as well. Finally, the very reliance on standards in Delaware law is not necessarily optimal either. It may well reflect an advantage Delaware gains from making its law dependent on its reputable adjudication services.

\footnotetext{
${ }^{82}$ See NY Bus Corp Law $\S 726$ (a)(3); 11 NY Comp Codes R \& Regs tit 1, § 72; 8 Del Code Ann § 145(g).
} 